\section{Inaumural Adùress}

\author{
on
}

\section{THE PAST OF DERMATOLOGY IN EDINBURGH.}

\author{
By NORMAN WALKER, M.D., F.R.C.P., \\ LECTURER ON DISEASES OF THE SKIN IN THE UNIVERSITY OF
}

Gentlemen,-Although the inauguration of a new lecturer is not surrounded by any university pomp and circumstance, and although I am not, I think, in most persons' minds so associated, I am, nevertheless, an upholder of a certain amount of form, and it does not seem to me fitting that I should take up the duties of this important post without some sort of introductory remarks.

I have so recently, in another place, and to another audience, dealt with the subject of the teaching of dermatology that it would be impossible for me to say anything fresh upon that subject, even if I had not before me the opportunity of practising what I have already preached.

I am a believer in introductory addresses to students, and would strongly advise you all to read the published ones of Osler, for I think it is good for the student, in the hurry and bustle of this extremely practical age, to now and then stop and either survey the present or, as I propose to do, to cast an eye backward on the past.

My purpose this morning is to go back and to recall the past of dermatology in Edinburgh, and to sketch for you some of those who have ploughed, sowed, and watered the harvest which it falls to my lot to gather, and I hope to do my share in preparing the ground for a yet more bountiful harvest in the future.

The first association of Edinburgh with dermatology which I have been able to trace is the fact that Willan, the father of British dermatology, was a graduate of our University. He was born in 1757 near Sedbergh, and educated at the famous Grammar School there. He came to Edinburgh in 1777, and graduated M.D. in 1780 . He practised with great success in London, began the publication of the famous atlas which was completed by his pupil Bateman, and was elected F.R.S. in 1809. Shortly thereafter he contracted phthisis, and went to live at Madeira there he died in 1812, in his 55th year.

Robert Willis was born in Scotland in 1799, and graduated M.D. in 1819. He appears to have commenced practice in Edinburgh, for it is recorded of him that he went to London in 1823. It is further recorded that, not succeeding so well as he expected, he threw himsel with great zeal into the paths of literature. In time he became editor of the London Medical Gazette, and subsequently the first librarian of the Royal College of Surgeons library. This he remained till 1845, when he resigned in order to devote himself to practice, "his official salary being quite inadequate to provide for an increasing family." $\mathrm{He}$ published an atlas of Illustrations of Cutaneous Diseases in 1848. He must not be confused with the more famous Willis, the Willis of the Circle, who also devoted some of his abundant energies to the subject of dermatology, into which his insight was as keen as into other matters medical.

These are merely interesting reminiscences, and the influence of Willan and Willis on the school can only have been indirect.

I have inquired of two of the veterans who in a vigorous old age are still among us, and who were students in Edinburgh in the Forties. Sir Henry Littlejohn says :

When a student in the school of medicine I never heard a lecture on skin diseases, and during my term of service in the clinical wards no skin patient was admitted or treated. In common with others, I had to go to Paris to receive instruction in this most important department of medical study.

Dr. John Smith's reply is in almost the same words.

The first man who did anything practical for dermatology in Edinburgh was John Hughes Bennett. This was only a part of his work; only those who have dipped a little into the history of the past, or whose fathers have spoken unto them, can dimly realize what the Edinburgh Medical School owes to John Hughes Bennett. Others have carried on and developed his work, but the admitted pre-eminence of this school in the subject of clinical medicine is the direct issue of his labours. He was born in London in 1812, and was apprenticed to a surgeon in Maidstone. There, in the manner of the day, he no doubt compounded medicines, drew teeth, and learned in the worst possible way the routine of practice before he knew anything of its principles. But his zeal for knowledge was great, and fortunately for us his zeal outran his discretion. He and another pupil one day made a postmortem examination without their master's knowledge, and his apprenticeship was abruptly terminated.

After anxious consultátion as to his future it was decided to send him to Edinburgh. He came here in 1833, and graduated M.D. in 1837 with the highest honours, obtaining a gold medal for the best surgical report on Syme's recommendation, while Sir Charles Bell recommended his thesis on the physiology and pathology of the brain for another, which, however, could not by the regulations be awarded. After graduating he spent two years in Paris and two years in Germany. I would draw your attention to the fact that his post-graduate equalled his undergraduate career.

When he returned to Edinburgh in 1841 he at once commenced to lecture in our Extramural School. Here are the words of his first class bill:

Histology.-Dr. Bennett, during the summer session, will give a public course of lectures on the Minute Structure of Organized Tissues, with reference to Anatomy, Physiology Pathology, and the Diagnosis of Disease. These lectures will be illustrated by numerous preparations, diagrams, and demonstrations under the microscope ; the latter by means of twelve achromatic instruments of great power. manufactured by achromatic instruments of great power, manufactured by Chevalier of Paris expressly for this course. An introductory lecture will be delivered on Friday, May 13th, at 11 a.m., in the Class Room, Surgeons' square, and the course will be continued every Monday, Wednesday, and Friday at
the same hour, throughout the session ; fee £2 2s. Dr. Bennett will also give private courses on the practical manipulation of the microscope. Each class is limited to six, and the time of lecture regulated by the wishes of the majority. The lectures embrace the optical and mechanical arrangements of microscopes, illumination, mensuration, optical illusions, mode of displaying objects; and every information necessary for the medical inquirer, in his examination of the animal textures in a state of health and disease. Fee $£ 33 \mathrm{~s}$. 16, Pitt Street. in a state of healt
May 2nd, 1842 .

Bennett's work as an extramural lecturer-he began his teaching in the Royal Public Dispensary-was mainly devoted to clinical medicine, where he introduced method and revolutionized the system of teaching. Hear and mark his words :

Clinical instruction is not attendance on lectures, not learning the opinion of your teachers. It is not deriving knowledge from others. It is acquiring information for yourselves, learning how to observe, educating the senses.

In 1842 he was an unsuccessful candidate for the chair of pathology, and it was not till 1848 that the chair of the institutes of medicine-now termed physiology-became vacant. The contest is an interesting one to look back upon. There were-three candidates, the others being Dr. Gunning and Dr. Martin Barry, whose fame as a physiologist was considerably greater than Bennett's.

But in those days there were religious tests applied to all the professors, and these Dr. Barry could not see his way to subscribe. The election was by the magistrates and town council, and as Drs. Gunning and Barry withdrew their names, Dr. Bennett was unanimously elected. It is rather interesting to note that, after he had been proposed by the Lord Provost and duly seconded, $\mathrm{Mr}$. Gulland, the grandfather of our Dr. Gulland, rose and said that the mere circumstance of tests existing had a tendency to prevent gentlemen from coming forward who would otherwise do so; and he therefore thought that they should urge the Government to bring in a Bill for the immediate abolition of these tests. Largely, I understand, owing to his energy, this was ultimately done, and neither professors nor University lecturers are any longer subject to that inquisition.

It was when he became a professor and shared in rotation with Laycock the charge of what were known as the clinical wards, that he found his opportunity of teaching dermatology. His introductory lecture to the course of clinical medicine delivered November 9th, 1849, concluded with these words :

We shall never rest contented until the Edinburgh School of Medicina is complete in all the means necessary for studying every kind of disease at the bedside. 
In a footnote to a clinical lecture on the Classification and Diagnosis of Cutaneous Diseases, published in April 1850, he was able to report:

Two wards, Nos. 12 and 2, which have for some time been in disuse, shall be resumed by the professors for the purpose of clinical instruction. It has in consequence been arranged by the Medical (th treatment of diseases peculiar Dr. Simpson (Sir James) having expressed his willingness to take charge of it, he will in future give clinical lectures on this important department of practical medicine. The Faculty has decided that the other ward shall be devoted to the reception of skin diseases, so that in this department also the facilities for study will be greatly increased. . . . No doubt the concessions granted enable us to make advance, but they are not sufficient. We must keep pace with other schools.

Bennett's most important contribution to dermatology was his work on Favus. He confirmed the observations of Schönlein, the discoverer of the fungus, and was one of the first, if not the first, to successfully inoculate the disease. He repeatedly tried to inoculate himself, first on the arm and then on the scalp, and finally succeeded on one of his students whom he had evidently inspired with his own enthusiasm. I regret that we only know that enthusiast under the contraction of Mr. M., but I commend to you his example. I have not time to refer to all Bennett's dermatological work. He evidently fully realized the importance of local causes in the production of dermatitis, and I am told by those who were his students that it was one of their delights to hear Bennett and Laycock explaining each other's theories away. By the rotation system they succeeded to each other's cases.

There are, however, one or two quotations that are of interest. One is extraordinary. "Ringworm," says he, " is a disease I have never seen in Edinburgh, and I am ignorant of what it consists." It is inconcievable that one so constant in the use of the microscope as Bennett could have overlooked the disease had it existed to anything like the extent it now does. One last quotation I especially commend to you :

The great difficulty in the treatment of skin diseases generally consists in their having been mismanaged in the early stages - a circumstance I attribute to their not having until a recent period been much studied -note the word-by clinical students.

After twenty years' occupancy of the chair his healtl began to fail; long leaves of absences were necessary, and he finally resigned his ehair in 1874. He died in 1875 at Norwich, aged 63 . He did whatever his hands found to do with all his might, and his works follow him.

It will, perhaps, surprise you to hear that the next name I put forward is that of Sir James Simpson. It is true his main energies lay in other directions, and that his connexion with dermatology was limited to one disease. But his researches on the history of leprosy in Scotland though of little practical value, are of much archaeological interest, and are well worth perusal.

It is necessary here, for the sake of clearness, to mention a fact of which you, gentlemen, are probably not awarenamely, that all the professors of the Medical Faculty at one time had-and I am not sure that they do not still have-the right to teach medicine clinically in the wards allotted by the managers to the University. The professors of chemistry, botany, anatomy, physiology, and medical jurisprudence have in the past exercised this right.

In virtue of it Sir Douglas Maclagan comes next in my roll, and here I am able to pass from hearsay to personal recollection, for when I was a student it was Maclagan we associated with skins. It is only a little over six years since he died full of years and honours in his $88 \mathrm{th}$ year. He had a remarkable career. He was educated at the High School, was admitted L.R.C.S. when he was 19, and became M.D. two years later. It is recorded that he was admitted thereto by the Commissioners appointed at the request of the University by the Royal College of Physicians. He owed yet another advantage to that College for his father being a Fellow he was exempt from the then necessary apprenticeship, the official means of clinical instruction. After graduating he studied in London, Paris and Berlin, and then returned to Edinburgh to practise. He began as a surgeon, and was for some time on the staff of the infirmary in that capacity, but his instincts were not surgical and he soon began to lecture on Materia Medica, and so continued for eighteen years until he was appointed Professor of Medical Jurisprudence and Public Health, which post he held for thirty-five years. As one of the Professors of Clinical Medicine he lectured in rotation, first with Bennett and Laycock, and later with their successors. When the new infirmary was opened, and he had a ward all his own, he devoted a great part of it to dermatology, and his clinical lectures were largely on that subject. I remember some of them well. He had great faith in tar, as all experienced dermatologists have, but I particularly associate him in the dermatological part of my mind with the advice to give iron in eczema. It seems to me that he advised it in all forms of the disease, and there I cannot agree with him; but it is very often indicated, and $I$ like to emphasize the advice, for one famous living dermatologist teaches that iron is contraindicated in that disease.

It is more, however, as a man than as a dermatologist that Maclagan is remembered. He was Ultimus Romanorum, the last of the old school of courtly physicians. As a toxicologist his fame was world-wide, and as a medical witness he was only equalled by his successor. He and his father enjoyed the unique distinction of filling the presidential chair of both our Royal Colleges.

If I might put it without offence-and no one could wilfully be guilty of saying anything offensive of Douglas Maclagan-I would say that the chief service he rendered to dermatology was the advice he one day gave to $\mathrm{Dr}$. Allan Jamieson to take up the special study of the subject.

Other physicians devoted some of their time to dermatology. Warburton Begbie now and then gave a lecture on some disease of the skin; and I would be singularly ungrateful if I omitted a reference to my own chief, Dr. Claud Muirhead. I have no doubt that it was his interest in the subject that first turned my thoughts towards it, and many generations of students have learned from the valuable set of casts which he gave me when he demitted office here. It was largely to his influence that I owed my first appointment to the staff.

Bennett's desire to see every subject taught in the Edinburgh School of Medicine was not immediately fulfilled. So long as the teaching of the special subjects depended, if one may so put it, on the individual hobbies of individual professors, it was obvious that it rested on an insecure basis. It was left to $\mathrm{my}$ immediate predecessor to place the teaching of dermatology on a sure foundation.

William Allan Jamieson was born in the manse of Dreghorn, near Irvine, in 1839, the year of the great tournament at Eglinton Castle. He was educated at the Irvine Academy, of which school he was dux, and graduated M.B., C.M., with honours, in this University in 1865. Had the Ettles Prize then been in existence it would have been awarded to him. After graduation he acted as assistant for two years to a relative in Preston. He then practised for nine years in that part of this island which until the passing of the County Councils Act of 1885 was neither in England nor Scotland-I mean the town and liberties of Berwick-on-Tweed. In 1876 he came to Edinburgh and commenced practice. Not long afterwards there occurred one of those-we call them chance-conversations which had far-reaching effects. Discussing his prospects one day with Douglas Maclagan and Douglas Argyll Robertson, the former suggested to him that he should devote himself to dermatology, and after consideration he decided to do so. On Maclagan's advice he gave up his work in Edinburgh and went to Vienna to study under Hebra, who was then the source of all dermatological inspiration.

On his return he commenced practice as a dermatologist, and $I$ fear he found it at first a weary business. Looking round our busy department now it is difficult to understand the arguments put forward against a skin department then. There were no cases; if there were any the ordinary physicians could easily deal with them, and so on. The old, old arguments-you will all meet with them in your future careers. The best he could do was to get the permission of the physicians of the Royal Public Dispensary, the same which gave Bennett his first opportunities, to become one of their number, and to encourage the attendance of skin cases. Later, he was allowed to drop the medical work and confine himself to skins.

At intervals he knocked at the door of the Royal 
Infirmary in vain and the opening came at last not by conviction, but as those things so often do, by chance. The chance came in an attack of eczema in one of the managers, and had Daniel Rutherford Haldane, the uncle of the Minister for War, not been cured of his eczema by Dr. Jamieson, we might not have been here to-day.

In 1887. permission was grudgingly given for the opening of an out-patient department, and for some years this was carried on in what is now our male ward, and was then the ear and throat, dental and skin out-patient department. Gradually the clinique grew, patients got more numerous, and students began to find out the advantages of learning something about skins. The numbers grew so great that it was found necessary to move to the extramural clinical theatre, where for some years Dr. Jamieson taught the greatest number of English-speaking students that have anywhere assembled to learn dermatology. All this was a labour of love; but as the students grew more and more numerous it was obvious that further advances required to be made and a regular class established. This last ditch took a long time to carry; the vested interests fought hard. Ultimately the managers gave permission to institute a class, and shortly after the University capitulated and appointed Allan Jamieson Lecturer in Dermatology.

Six beds were allotted to him in 1891, and the numbers have gradually increased to sixteen. When the redrainage scheme is completed the number will be trenty-four.

Thus at last Bennett's ambitions were fulfilled, and, so far as dermatology is concerned, "the Edinburgh School of Medicine is complete in all the means necessary for studying every kind of disease at the bedside."

In 1886 Sir Henry Littlejohn, in whose gift the post is, offered to Dr. Jamieson the Consulting and Visiting Physicianship of the Edinburgh City Hospital for Infectious Diseases, then established independently. This afforded him the opportunity of pointing out, among other things, the diagnostic features of the exanthemata and the characteristics of erysipelas, and during the five years he held office there he found the hospital most valuable for teaching purposes, as well as for research. He resigned on the opening of wards for dermatology in the Royal Infirmary.

This is not the time to dwell on what Allap Jamieson has done for dermatology at large-to have established the subject on a firm footing in the greatest British school of medicine is a triumph which might make the humblest man proud.

One personal word. We have worked together for fourteen years, his kindness and generosity to me have been beyond praise, and the only cloud on my natural gratification on my promotion to this proud position is the fact that it involves his retirement.

In the college honours that will before long be offered him we all, I am sure, wish him much enjoyment and happiness.

And now, Gentlemen, I have dealt with the past, and we look forward to the future. It shall be my ambition to follow Bennett's principles and to endeavour to teach you to observe for yourselves. This, I believe, can only be done in small classes, and, though I shall deliver lectures here, I shall regard the limited classes which I shall teach on the other days of the week as at least as important parts of the course.

In the anonymous articles on the teaching of medicine which are appearing in the Scottish Medical and Surgical Journal, and which it is my editorial duty and privilege to peruse in their unabridged form, you will find a striking unanimity in the view that students waste their time at operations. Between the hours of 11 and 12 there are many departments of the hospital where time may well be spent. I can assure you that in your after-career you will not regret the three or four hours a week which I ask you for the next ten weeks to devote to dermatology.

ANTwerp Exposition.-An international exposition is to be held at Antwern in A pril. May and June 1907, under the patronage of Her Royal Highness the Countess of Flanders. There will be a Medico-Pharmaceutical Section, including within its scope exhibits relating to hygiene, food, and beverages (wine. liqueurs, beer). Full particulars can be obtained by application to the Secretary's Office 30, Rue d'arenberg, Anvers (Antwerp).

\section{A oliniral $\mathfrak{l}$ erture}

ox

\section{THE ACTION OF SALICYLATES IN ACUTE RHEUMATISM.}

BY RALPH STOCKMAN, M.D.,

PROFESSOR OF MATERIA MEDICA IN THE UNIVERSITY OF GLASGOW, AND PHYSICIAN TO THE WESTERN INFIRMARY.

SALICYLIC ACID had been well known to chemists for about half a century when Kolbe, in the course of a research on chemical constitution, succeeded in making it on a large scale from phenol, and announced in a series of papers published in 1874-5 that it was a powerful antiputrefactive and antifermentative, capable in dilute solution of killing low organisms and of annulling the action of yeast, pepsin, emulsin, and similar ferments. He recommended its use in medicine as an antipyretic and antiseptic, with the result that Buss, while investigating its action in various febrile conditions, observed that it was specially valuable in acute rheumatism-a discovery which was amply confirmed by Stricker in 1876. In the same year J. T Maclagan published an account of his successful treatment of rheumatic fever with large doses of salicin. Since then salicylic compounds have been universally relied upon for the treatment of acute rheumatism, most authorities regarding them as exercising a specific action on the cause of the disease, which is now generally assumed to be a microbe. Previous to the introduction of salicylates such drugs as aconite veratrum, colchicum, quinine, alkalis, opium, and a host of others, had been in vogue, but they had for the most part come to be regarded as either quite useless, or at best very unsatisfactory in their curative effects. Under the administration of these, cases of acute rheumatism probably all ran their normal course until a natural cure resulted, but with the difference, as compared with many other fevers, of having no definite limit of duration. From three to six weeks used to be a common computation, but many cases lasted much longer either with successive exacerbations or with continuous sligl t fever, while others recovered in two or three weeks, or even in a few days. Whether the natural cure results from an antitoxic or from an antibacterial substance formed in the body is unknown, but it is evident that this hypothetical body is of satisfactory amount and potency in some cases, while in the majority it fails to rapidly and completely cut short the disease. During the fever there is a moderate leucocytosis, and one attack rredisposes to others instead of acting as a protective.

In the absence of any certain knowledge regarding the specific microbe of acute rheumatism and its toxins, it is impossible to determine experimentally whether salicyl compounds act as bactericides or as antitoxins in the disease. When we try to solve the problem indirectly by studying their effects on known organisms and ferments, we find that salicylic acid and its sodium salt are capable of preventing the action both of living ferments and of enzymes outside the body, so that in the body their action might conceivably be exerted in either or both directions. These are questions, however, of which the settlement can be attained only by further research, and which cannot be profitably discussed in a clinical lecture. When salicylates are given in sufficient dose in an uncomplicated case of rheumatic fever, the pain in the joints and the temperature begin to be favourably affected at once, the former subsiding in twelve to twenty-four hours and the latter within forty-eight hours. The joint swelling disappears in two to four days, and the freguency of pulse and respiration diminishes with the fall of temperature. The course of events closely resembles a crisis in fever.

The Charts 1 and 2 show the immediate and continuous drop of temperature, accompanied by cessation of pain and the fall in pulse-rate which characterize the successful action of sodium salicylate. In Chart 2 the accidental omission of three doses was followed by a slight rise which quickly subsided on resuming the medicine.

In Charts 3 and 4 the course of the temperature resembles the "nseudo-crisis" which is so common in pneu nonia, and, li'se it, is followed by a definite termir.a- 